\title{
Karubiu wa Munyi and the making of modern Kirinyaga, Kenya
}

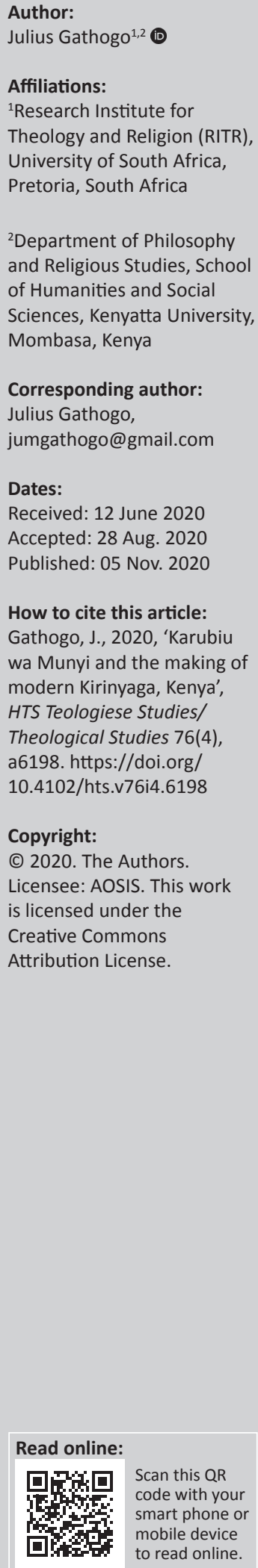

The article sets out to explore the lessons that can be drawn from the selfless and integritydriven leadership offered by some pioneer post-independent Kenyan leaders such as Karubiu wa Munyi. With more financial scandals increasing in the public domains, as in the case where over 15 mega corruption scandals remained unaccounted for, by 2018, the need to draw some lessons from the likes of wa Munyi becomes an important matter worth consideration in the 21st century. As we seek to demolish both colonial mentality and neo-colonialism in the 21st century, there is a need to reconstruct the memories of some of our key actors in our African societies, as we seek to rebuild our respective contexts. Having lived under deadly and complicated theo-historical times, but eventually overcame hunger and famine, war, colonial bombs and general poverty, the article hypothesises, he stands out on a pedestal and remains a critical reflective case for masses of people who are walking through the valleys and shadows of death in Africa and beyond. In its methodology, the article develops mainly from the researchers' interviews with wa Munyi who is eventually chronicled, as it seeks to ascertain whether there are lessons to draw from his 'philanthropic' and integrity-driven leadership. Was the virtue-driven leadership of Karubiu wa Munyi a by-product of Africa's Ubuntu [caring for the other] cultural heritage and the evangelical Anglican Christianity that settled in his locality since 1912? And has the society lost its cultural morality and the virtue-leaning evangelical Christianity that was ushered in by the Church Mission Society at the beginning of the 20th century? In this article, Gitugi kia bururi [the critical cornerstone] - the casual description of wa Munyi - symbolises the ideal leaders who remain at peace with themselves and the general society even after retiring from active public duties; as their respective consciences are above board. Africa has to take lessons from such selfless leaders. The materials in this article are gathered through interviews with wa Munyi and other people who are connected to issues under consideration. A review of relevant literature has also been done.

Contribution: The article adds to the growing knowledge by its originality; a phenomenon where a little-known civic leader (Karubiu wa Munyi) is used as a lens through which we can understand the modern day Africa. Has the continent that sought independence from the colonialists who came after the Berlin Conference of 15 November 1884 to 26 February 1885 recolonising itself through neo-colonialism and corrupt practices of unimaginable proportions? The article is relevant to the HTS Journal and the world of scholarship as it shows God's works in history, as it confirms that a people who walk through the desolate valleys and shadows of death, and are starring at the total annihilation, do also have a future.

Keywords: Ideal African leadership; neo-colonialism; colonialism; Karubiu wa Munyi; leadership lessons; corruption.

\section{Introduction}

As Kenya celebrates 57 years of constitutional independence (1963-2020), and as 15 mega corruption scandals remained unaccounted for, by 2020, it is worthwhile to ask a variety of questions. Firstly, will Kenya recover and be guided by selfless leadership akin to the pioneer leadership that ushered in our independence in 1950s and 1960s, right from the grassroots? Secondly, shall the role of the 'founders' inform the new crop of leadership as a measure of improving their lot? And more specifically, what lessons can we draw from the integrity display and the selfless role of the likes of Councillor Karubiu wa Munyi amidst regrettable cases such as those of the National Youth Service (NYS) of 2018, where over Kenya Shillings 8 billion were reportedly lost in a notorious supplies payment hijack scheme, dubbed as 'supplying air', a phenomenon where faked documents were used to pay ghost suppliers? 
Between June and September 2018, the Kenyan Deputy Public Prosecutor (Noordin Haji) approved the prosecution of 30 people who included the officials of the Kenya Ports Authority (KPA), the Kenya Bureau of Standards (Kebs) and the Kenya Revenue Authority (KRA) in relation with the alleged import of poisonous sugar, rice and fertilizer, which cost the Kenyan taxpayers well over 10 bn Shillings. Around the same time, some Kenya Power officials were accused of misappropriating 400 million shillings ( $\$ 4 \mathrm{~m}$ ) through faulty transformers deal with Muwa Trading Company and so on (Wasuna 2019). Other scandals include: the National Cereals and Produce Board (NCPB) Maize scandal (KSh 1.9 bn), the first NYS scandal (KSh $791 \mathrm{~m}$ ) of 2015, the second NYS scandal (KSh 9 bn) of May 2018, the Afya House scandal (KSh 5 bn) of October 2016, the Galana and Mwea Irrigation Scheme scandal (KSh 3.5 bn) of 2015 and 2016, E. K. Foundation scandal (KSh 2.7 bn) of 2016, the Chickengate scandal (KSh $59 \mathrm{~m}$ ) of March 2013, the Goldenberg scandal (KSh 100 bn) of 1990s, the Anglo-leasing scandal of 1997 and the Karen land scam, amongst others (Onyango 2019).

Such cases have remained the defining characteristic in the post-independence Kenya, and in the post-colonial Africa. In turn, it drives us to wonder: Were we ready for political independence and eventually willing to manage our affairs prudently? Are there selfless and integrity-driven leaders in post-colonial Kenya, and Kirinyaga County in particular, since 1963 worth consideration? This leads us to survey the lifetimes of Councilor Karubiu wa Munyi, who was one of the freedom fighters turned lay Anglican Church leader, a grassroots leader and a businessman in the rural areas of Kirinyaga County of Kenya.

With selfless and integrity-driven leadership such as those of Munyi, I argue that malpractices in society would be minimised or eradicated altogether if virtues become the defining characteristic of an emerging society. Certainly, celebrating the contribution of selfless and integrity-driven leaders is a positive step that encourages the virtue of selfless service to God and humanity. In studying the lifetimes of the likes of Karubiu wa Munyi (1925-), the incoming generations have a vital lesson to learn from this Civic Leader who lived in peacefully and humbly upon his retirement, as he was not feeling guilty of any 'wrong doing' to the public.

\section{Karubiu wa Munyi}

Munyi began his school education at Kangware Primary School in 1937. Kangware Primary School was later moved to the present site (Manyatta) in 1957 and was renamed as Kagumo Primary School. Unlike at Kangware, the Kagumo Primary School was allocated a piece of land, and a title deed was issued hence securing its permanency in the new site. The reason for its transfer to its present site was the local Churches who complained that it was too near the Anglican-sponsored Kiamaina Primary School, yet Kagumo was (and still is) a Roman Catholic sponsored Primary School. By 1953, Kangware Primary School was still at Kangware site, though the process of removing it from the site began in 1954 as villagisation policy, as in Nazi Germany of 1930s, was being implemented in colonial Kenya so as to contain the Mau-Mau (freedom fighters) insurgencies. In this scenario, people were forcefully removed from their homes and put in 854 villages across the country, and especially within the so-called Mount Kenya region.

In these concentrated villages, or camps, in the African reserves, the designated areas were cordoned off with barbed wires. Julius Gathogo and Cyrus Njogu (2019) have aptly captured the 1950s situation, thus:

After the State of Emergency was declared [on 20 October 1952], people of central Kenya were put in villages, in what later came to be referred to as 'villagisation'. By June 1954, the War Council took the decision to enforce villagisation throughout Kikuyu land. By villagisation, it means the compulsory resettlement of people from their scattered, ridge-top farms, into centralized, regulated villages, situated at key points along the busier roads. While some villages were principally meant to protect the loyalists, most of the 854 established villages or camps were in reality, mass detention camps intended to punish Mau-Mau sympathisers. In turn, this negatively affected the trend in Anglican missions - as most of her members were the key targets and suspects. [Again, martyrdom of confessing Christians by MauMau rebels was commonplace, as revivalist Anglicans and Presbyterians were seen as agents of colonialism - even though Schools, whose education enlightened the general populace, belonged to the respective Churches]. (p. 22)

This compulsory resettlement into centralised and regulated villages means that Karubiu wa Munyi's School (Kangware primary) would be greatly affected, hence its shift to Manyatta (and renamed Kagumo primary), as forceful removals meant that it could not attract enough learners. Certainly, most schools in the locality were seen as temporary learning centres, as the occupied lands were not yet settled and/or provided with legal documents. An exceptional case was Mutira Primary School, where the three acres for the Anglican Church and the 12 acres of the primary school were 'permanently' secured in as early as 1908, when a European missionary, Arthur Wallace McGregor, allegedly 'bought' the land from the locals. The land belonged to Ithimbwi family of Wanjiku clan (Gathogo 2011a:20). As noted in Gathogo (2011a:20), McGregor came to the hill of Mutira (Njumbi-Mutira) from Mbiri District (later Fort Hall and currently called Murang'a), accompanied by some fellow Europeans and two Africans, namely Paul Kigondu and Thomas Meero.

Upon their arrival, they met lots of resistance from the local Ithimbwi clan of Agaciku clan, who did not want their 15 acres of land to be taken away by the 'foreigners' in pursuit of building school (12 acres) and Church (3 acres). Following this resistance, the missionaries, under Rev McGregor, left for Kabare and Kigari-Embu and by 1910 established the respective station. Gathogo (2011a) goes on to explain that it was only in 1908 that the:

$[L]$ and was finally bought by Rev. McGregor from one, Karunditu wa Gitura, at a cost of 30 Rupees (approximately KES 60/= then 
but today in 2012, about KES 600000 OR \$7500). The deal was witnessed by his half-brother Gacubi. McGregor then placed a placard on a Muthariti tree to indicate that the land had already been bought. Interestingly, not much is known about Karunditu wa Gitura for he died soon after. After the 1908 encounter in Mutira, where resistance threatened to permanently stop the missionary work, McGregor proceeded to Kabare and Kigari and bought land for the Mission centre by 1910. As a result, a Church was built (Anglican) there by 1912 with the supervision of Rev McGregor. McGregor who had started his mission work in the Taveta area in early 1892 is the one who had also began an Anglican Centre at Kabete on 13 October 1900. (p. 20)

Although wa Munyi joined the then 'Mud' house (Mutira Primary School) after stints at Kangware Primary School, he had to stop schooling in 1941 because of poverty-related factors. From there, he left for Nairobi so as to look for a job. He later left for Nakuru so as to look for greener pastures. Critically important is the great hunger of 1941 ( $\mathrm{Ng}^{\prime}$ aragu ya Mianga - the Cassava famine) that affected him greatly.

\section{The European famine}

In turn, the so-called Cassava famine ( $\mathrm{Ng}^{\prime}$ aragu ya Mianga) compares with the earlier $\mathrm{Ng}^{\prime}$ aragu ya Ruraya [the incoming European-triggered famine], which was associated with the coming of Europeans in central Kenya. It took place between 1898 and 1899. As noted in Evanson Wamagatta (1988:60, 2016:21):

The famine, which was preceded by a locust invasion in 1898 and compounded by an outbreak of smallpox [had] the [neighboring] Kiambu people [as] the hardest hit, [as] their trading activities [depleted] their food stocks at a time when cultivation had significantly decreased due to the disturbed situation. ... The famine demonstrated that only the fittest and strongest could survive. The social and political fabric appeared to snap and collapse. Bands of marauding Kikuyu warrior brigands, known as thabari, sprang up. They were akin to the Yao and Ngoni ruga ruga bands who terrorised southern Tanzania in the second half of the nineteenth century. The thabari, the most notorious and daring of which came from Kiganjo Location of Gatundu Division, raided far and wide and terrorised all and sundry.

John Patterson (cited in Wamagatta 2016:17) of the Church of Scotland Mission, at Kikuyu (Kiambu County), explains the situations, where there was a huge breakdown of law and order, especially in regard to the present day Kiambu County, thus:

During the famine [of Europe], it was a question of the survival of the fittest. The poor people simply died and the rich survived. I remember one case where a man had about 15 goats and the Chief, Munyua, killed him in order to get the goats. Indeed, the chiefs at that time killed their own poor people. There were many deeds done in those days which would not be tolerated today... People were dying of smallpox and drought. The banks of the streams were strewn with dead bodies, so much so that the hyenas could not dispose of them. We tried to bury some of them, but the task was impossible so we had to give up. (Wamagatta 1988:62)
Like other famines, noted in this article, the 1898-1899 European-triggered famine ( $\mathrm{Ng}^{\prime}$ aragu ya Ruraya) devastated the present-day Kirinyaga, the larger Mount Kenya region and the adjacent areas. The famine was preceded by a locust invasion in 1898 and compounded by an outbreak of smallpox. It was further compounded by three consecutive rainless seasons. Further, farming activities had decreased as a result of the disturbed situations as the influx of 'foreigners' created uncertainties that negatively affected their usual activities. In turn, $\mathrm{Ng}^{\prime}$ aragu ya Ruraya [the European Famine] in Mount Kenya region reduced survivors to mere scavengers and skeletons who ate anything palatable, including banana tree stumps (Cienja cia marigu), and hides amongst other things, in a desperate attempt to stay alive. In the ensuing milieu, only the strongest survived. Certainly, this famine decimated the population of the people of central Kenya (Wamagatta 1988:60, 2016:21).

\section{John Boyes and the European famine}

As noted thus, this 'European famine' was allegedly caused by the confusion that came with the incoming Europeans to central Kenya who were domineering, destructive, disruptive and interfered with the vicissitudes of life. A case in point is a European imperialist, John Boyes (1875-1951), who was nicknamed Karianjahi, meaning 'the eater of Turtle Beans' by the locals. Boyes settled in the present-day Murang'a Town (then called Mbiri, later turned the 'regional' Headquarters) in 1898 (Boyes 1912:3). He became a polygamous European settler-administrator, after marrying three Kikuyu wives. He disrupted farming activities when he and other 'strange people' (Europeans) came with all manner of indiscipline. Boyes formed a warrior-army of 5000 uniformed Kikuyu men in 1899 (Boyes 1912:6). He then made a weird claim that he had bought Mount Kenya after subtly giving 10 cows to 'Chief' Wang'ombe wa Ihura and 10 cows to 'Chief' Olomondo of Dorobo people (the hunters) (Boyes 1912:7).

This raises several questions: Considering that the mountain remained the symbol of religious consciousness of the people living around its slopes, were Olomodo and Wang'ombe wa Ihura in a position to sell it even if they were self-declared community leaders? Certainly, they did not own the mountain; and indeed the mountain was not for sale; as the sacred mountain of Ngai [God] could not be advertised and bidders invited for sale. To an extent, this was an open declaration of war with the Gikuyu God (Ngai). It is interesting that Karianjahi (Boyes) went on to declare himself the King of Wa-Kikuyu, even when Meru, Kikuyu, Kamba, Mbeere and Embu did not have Kings for their leaders.

In his authored book, King of the Wa-Kikuyu: A True Story of Travel and Adventure in Africa, Boyes (1912:10) prides himself for being the first King of Wa-Kikuyu. With such invading and imperialistic characters who had superior arms, the European famine of 1898 was bound to take place as they created fears of abrupt attacks whilst people were farming in 
their fertile lands. The beauty in this European famine is that it helps us to understand the disruptive consequences of the latter famines, some of which had huge impacts on Karubiu wa Munyi's formation as a modern leader. Such famines include: the Thika dirge of 1918, the Cassava famine of 1941 and the Government famine of 1984, amongst others.

To understand the situation that wa Munyi grew in, it is therefore necessary to understand the famine threats which were the order of the day, even though some were more fatal than the other. Additionally, it is worthwhile to concede that it is during this 1899 famine that a Mukurweini (Nyeri) family (precisely brothers) sold their 13-yearold daughter/sister to the so-called Bururi wa Ndia [the eating country, now Kirinyaga], which was less hit, and was traded and/or exchanged with sacks of food. This lady, who later came to be christened Tabitha Karingo, in early 1920s at the Mutira mission centre, eventually got married to Mururia (also called Kiragu owing to his role as an African medicine man and a seer) when she came of age, and they subsequently bore Wairangi, Wanduma, Nathan, Ishmael Gaite and Waruguru. She ended up as the unsung heroine in the old Embu district, which had the present-day Embu and Kirinyaga counties (Gathogo 2011b:156-157).

Like Karubiu wa Munyi, Tabitha Karingo became a heroine because of the way she bravely fought (like Professor Wangari Maathai, the Nobel Peace Laureate of 2004) against matters touching on the peoples' survival. In particular, Tabitha Karingo fought against cultures that were inimical to the dignity of women (Gathogo 2013a:157). In other words, she fought against forced 'wife inheritance' (guthambio ritual), demeaning inferences and female genital mutilations (FGM), amongst other sexist and patriarchal malpractices. This animated, reenergised and renewed Tabitha Karingo emerged after her conversion to Christianity around 1920.

\section{The Cassava famine factor}

Another major famine to hit central Kenya was the Thika dirge ( $\mathrm{Ng}^{\prime}$ aragu ya Thika) of 1918. As noted in Julius Gathogo, 'The 1918 famine was caused by locust invasions of the farms where they ate all the plants in the area surrounding Mutira' (Gathogo 2013a:108). This, however, came before wa Munyi was born in 1925. In the case of Cassava famine ( $\mathrm{Ng}^{\prime}$ aragu ya Mianga) of 1941 to 1944, which equally had life-threatening effects, Joseph Barrage Wanjui (2009:17-18) avers that the central region (also referred to as Mt. Kenya region) maize, the staple food, had run into short supply. To this end, Cassava flour was used as a substitute; hence the reason for its being renamed Cassava famine ( $\mathrm{Ng}^{\prime}$ aragu ya Mianga). Wanjui (2009) further explains that:

Cassava is a hardy food plant that survives drought far better than maize. People commonly preferred eating it whole, either boiled or roasted. However, only in times of extreme famine was its flour used as staple [by the people of Kirinyaga]. (p. 17)
Wanjui (2009:18) further explains that the inhabitants of Central Kenya (also called Mt. Kenya region) were more severely hit by the 1941-44 famine than those from the region who had already migrated to the Rift Valley region of Kenya. In the latter, the land was more fertile and the maize crop had not failed as in the former. As a result, families in central Kenya who had their relatives residing in the Rift Valley had food supplies sent to them. Unfortunately for wa Munyi (Gitugi kia bururi), his family had no 'ambassadors' from that end. Consequently, they navigated through the troubled waters to the whole hog. Thus, Karubiu wa Munyi's encounter with the Cassava famine ( $\mathrm{Ng}^{\prime}$ aragu ya Mianga) of 1941 to 1944 was ironically a great lesson that prepared him for difficult leadership and survival skills afterwards.

\section{Return to Kirinyaga and subsequent arrest}

In 1942, Karubiu wa Munyi returned to the present-day Kirinyaga County, as a disappointed man, after failing to secure a job in both Nairobi and Nakuru counties, then districts. Indeed, hunger that was facing the country made it impossible for him to secure a job. He left Kirinyaga again in 1944 to Nairobi so as to do odd jobs such as pushing carts (Mikokoteni), washing cars, assisting in construction works and so on. After 2 years, he returned to Kirinyaga and undertook farming activities. From eyewitness account, Munyi's hard work was visible to the locals, as he had planted cabbages in Rwamburi area, near Kagumo Town that was inspirational and enviable.

Despite marrying in 1947, he still left his wife in the village and went back to the city of Nairobi to look for greener pastures. He would buy sugarcane in Kirinyaga County and would then take it to Kariokor (Nairobi County) for trading before the declaration of the State of Emergency, in the colonial Kenya (1948-1952). In turn, the State of Emergency was declared on 20 October 1952, following the arrival of Sir Evelyn Baring as the Crown of the Kenya colony of the British government (Gathogo \& Njogu 2019:3). Baring signed an order that declared a State of Emergency, from 1952 to 1960, a phenomenon where Operation Jock Scott was launched, and was characterised by a mass-arrest of the leading African nationalist (Jomo Kenyatta) and 180 other alleged Mau-Mau leaders, the freedom fighters (Gathogo \& Njogu 2019:4).

Others who were arrested during the operation dubbed 'Operation Jock Scott' were Fred Kubai, Bildad Kagia, Richard Achieng Oneko, Peter Gatabaki, Joel Kuria, Willy Jimmy Wambugu Maina, Victor Wokabi, Gakaara Wanjau, Sarah Sarai and Rebecca Njeri (Korir 2018:22). Amongst those who were arrested on 20 October 1952 from Kirinyaga County included Rumano Njamumo Gikunju (1920-1996), who eventually became the pioneer Senator of Kirinyaga in May 1963. The arrested Mau-Mau (freedom fighters) suspects in 1950s were taken to prison camps in the then Northern Frontier District (NFD), later renamed North Eastern Province (Korir 2018:22). 
Afterwards, in late 1952 and early 1953, Mungururio (mass arrests) saw the arrests of Karubiu wa Munyi, Nahashon Ngare Rukenya, Josphat Gathogo Kamoni and Charles Makumi Kimutwa, amongst others from Karubiu wa Munyi's Mutira location of Kirinyaga County. They were shuttled from one detention camp to the other in the remotest parts of Kenya. That is, Athi River, Manda Island in Lamu, Sayusi Island in Lamu county, Gathigiriri in mosquito-infested Mwea, Hola in Tana River District, Manyani, Mackinnon Road and Mbagathi, amongst other places. Others were taken to Kismayu, in the then British Somaliland. In particular, Karubiu wa Munyi was detained in 1954 and immediately taken to Embu Concentration Camp. He was later taken to Lang'ata detention camp and then to Manyani prison after a month. In 1955, he was taken to Kanja, Embu County. At the end of 1956, wa Munyi was taken to Kangaita detention camp up to 1958, after which he returned to peasant life. Munyi's arrest came after the first operation in Ndia (western Kirinyaga) of early 1953 that saw the arrest of Jackan Komu, Gutu wa Ndieri, Karenga Mwere, Nyamu wa Matere and Kiruma wa Mbutei (Karubiu wa Munyi, interviewed 24 November 2010).

In my interviews with Councilor Karubiu wa Munyi on 24 November 2010, it came out clearly that Mau-Mau arrests were nothing but mere smokescreen, as betrayals, petty rivalries amongst neighbours, personal vendetta, and outright hatred amongst rival families informed the nature of arrests and subsequent detentions. There were cases where cousins betrayed one another, as in the case where Jackan Komu was betrayed by a powerful colonial chief who was an age mate and a first cousin. He was immediately arrested and taken to various Mau-Mau detention camps where torture was inflicted upon him (Karubiu wa Munyi, interviewed 24 November 2010). Such Mau-Mau detainees were accused of being dangerous to peace and security.

\section{Life in Mau-Mau detention camps}

In the Kenyan Mau-Mau prisons across the country, Karubiu wa Munyi recalled, during an interview on 24 November 2010, that they were beaten, tortured, maimed, insulted, mocked and at worst killed. In the case of Manyani detention camp where Josphat Kathogo wa Kamoni and Karubiu wa Munyi were held, some Mau-Mau suspects died of typhoid as the feeding conditions encouraged this. This was compounded by the denial of medicine. In particular, wa Munyi recalled that over 400 people died in Manyani prison because of typhoid, though the propagandist report from the colonial government gave the 1950s deaths as 40 people only. At the extremely cold Kangaita detention camp, they were made to plant tea stems for the government. They also dug trenches, in early 1955. At Kanja-Embu, they were made to dig trenches so as to ensure that the Mau-Mau rebels remained in the forest (Karubiu Munyi, interviewed 24 November 2010).

\section{Life after Mau Mau prison}

Upon his release in 1958, Karubiu wa Munyi became a charcoal burner and indeed traded in charcoal. He also kept tea nursery beds, and was eventually employed at Gatwe to attend to the nursery beds, from 1959 to 1960. Such employees were paid 30 shillings per month, hence one shilling per day. As he attended Gatwe tea nursery beds, he also started a business at Kiamaina village from 1959 to 1960. At his Kiamaina shop, he sold charcoal, sugar, salt and other household goods. Later in 1960, he opened a shop at Kagumo Town, where he sold clothes, food, maize, cement and hardware, amongst other items. After 6 months at Gatwe tea nursery beds, wa Munyi got employed at Mutira Farmers Society (MFS), which had just been constructed in 1960 .

At MFS, wa Munyi did manual duties with Muriuki wa Kamaara, who was the then factory manager. Others include Gachoki Kibui who was also employed as factory labourer. From a short stint as MFS labourer, wa Munyi was transferred to the post of a factory watchman within the factory, in 1961. In other words, the MFS duty roaster changed from time to time. At the end of 1960, he left MFS and went to Nairobi, where he established a shop called Mutira Provision Stores at Nyamakima, Nakuru Stage, Nairobi. This shop was jointly owned by Karubiu wa Munyi, Allan Gachoki, Kinyua Gichoya, Gachoki Murage, Gatimu Nguru, Kinyua Mbute and Kinyua Gatere (interview with Karubiu wa Munyi, 24 November 2010). They sold goods on rotational basis. In 1961, wa Munyi was also taking charcoal to Nairobi for trading. It was made from wattle (Muthanduku) tree, the botanical name of which is Acacia mearnsii De Wild (Gathogo 2013b:33-56).

\section{Munyi as an elected leader}

Karubiu wa Munyi first sought to excel in business before venturing into elective politics, after which he was economically stable. In 1969, he built his first business house, a permanent building, at Gathuthuma. He also built a business house at Kerugoya Town in 1970 and went on to carry out his personal businesses in these buildings till 1974, when he started renting them out to others who were business-minded (interview with Karubiu wa Munyi, 24 November 2010). Munyi also entrenched himself deeply in the communal activities where he ended up as one of the pioneer members of the Board of Management (BOM) of Mutira Girls' High School from 1971 to 1978.

Other members of the BOM were Hon John Matere Keriri (Chair), Wambeti Njagi (Principal/Secretary after 1978), James Njogu Mabu (Treasurer), Chief Erastus Mwai Ngunju, Pricilla Wangui Muriuki, Janet Mithamo, Chief Stephen Ngigi Machere and the succeeding Anglican priests based at Emmanuel Church Mutira. In particular, the serving priests, as Mutira Girls' High School began in 1971, was Rev. Zachariah Nyaga Karani (1971-1975). Others who followed and remained members of the BOM were Rev. Godfrey Ngigi 
Ndirima (1976-1978) and Rev. Peter Karanja Njoroge (1980 to 1981), amongst others.

According to the veteran Principal, Dr Wambeti Njagi (then Mrs Njagi), who is accredited for raising Mutira Girls' Secondary School from a miniature school to a highly performing school, as a result of the good foundation that she laid (1978 to 2000), Karubiu wa Munyi was very supportive and constructive in matters that were growthoriented (interview with Wambeti Njagi, 24 August 2019). In turn, Dr Wambeti Njagi joined Mutira Girls' Secondary School, as the Headmistress/Principal, in 1978 and left in 2000. She then joined Ngiriambu Girls' High School in 2001 and in 2002 she became the Principal. Afterwards, she joined Kamwenja Teacher's College, from 2003 to 2008, and then went for retirement. Whilst Kamwenja Teachers' College, where Dr. Njagi taught, is sponsored by Nyeri Catholic Arch-diocese, Mutira Girls' and Ngiriambu Girls' are Anglican-sponsored schools. The former was started in 1924 by 'Bishop Perlo Vicar Apostolic of Nyeri under the sponsorship of Consolata Missionary Society' (Tablino 2006:139).

As it came out from the researcher's interviews with Dr. Wambeti Njagi, on 24 August 2019, wa Munyi lobbied MFS to build several dormitories that obtain in Mutira Girls' single-handedly. Being in the category of the so-called Harambee or Self-help School, Mutira Girls' did not receive government subsidies, as locals were tasked with the role of growing their respective schools (interview with Karubiu wa Munyi, 24 November 2010). With wa Munyi being a very influential person in the society, he would conscientise the locals to build their school. He also worked closely with the pioneer Chairman (John Matere Keriri) who was leading the Development Finance Company of Kenya (DFCK), and who ended up as the Ndia (now Ndia and Kirinyaga Central constituencies) Member of Parliament in 1983.

Although the idea of establishing Mutira Girls' Secondary school came in as early as 1965 when Rev. Joseph Mwangi Ngoro was the parish priest of Emmanuel Church Mutira, it matured in 1971 when the first Form One class began. The era of Rev. Joseph Kangangi Mwanake (from 1966 to 1970) equally did not see the commencement of Mutira Girls', though it prepared the final ground. As an Anglicansponsored school, the input of the Church was critically important. In view of this, Karubiu wa Munyi worked hand-in-hand with the Anglican Church in order to realise the dream of opening a Girls' School in the larger Mutira location which had two other secondary schools. That is, the Njega Mixed Secondary School that was converted to a Boys' only Secondary School in 1998, and whose idea had been mooted in 1965 but opened its first Form One class in 1968; and Kamuiru Boys' Secondary that had opened its Form One class in 1964 as a mixed school but left for Boys' only in 1972 (interview with Rev. Peterson Kiragu, 29 May 2020). Together with Chief Erastus Mwai wa Ngunju, they would raise money for constructing permanent buildings (as dormitories and classes).

It is no wonder that wa Munyi was appointed a BOM member in order to represent the local community interests. According to Wambeti Njagi (interview 24 August 2019), wa Munyi continued as a member of the BOM till he was elected as the Councilor of Mutira Location in December 1979, a position that has now been replaced with that of a Member of County Assembly (MCA), as locations were also replaced with wards. This change was effected after the promulgation of the new Kenyan constitution in August 2010 (interview with Wambeti Njagi, 24 August 2019). After his electoral victory in 1979, he continued to support Mutira Girls' High School through providing Kirinyaga County Council bursaries to the needy students from his Mutira location. He also continued lobbying for more resources from individuals and institutions.

Despite losing to Mr Mugo wa Nyaga in the 1974 general elections, Karubiu wa Munyi was able to outdo the former in the 1979 general elections. He was re-elected in 1983 but was openly rigged out during the infamous 1988 mlolongo (queuing) elections in Kenya when the single-party dictatorship organised electoral malpractices that rigged out certain candidates, seen to be 'disloyal' to it (interview with Wambeti Njagi, 24 August 2019). Wa Munyi, however, remained a respected elder in the society, a good farmer and a businessman who supported Church and societal activities, just as in the past.

\section{Some regrets}

In my interviews with him, I gathered that though he was proud of his achievements, during his heydays, he was still regretful that the ruling party, Kenya African National Union (KANU), went on to rig out some candidates in the infamous 1988 mlolongo [queuing] elections in Kenya. Were the 'parents' (the erstwhile ruling party KANU) fighting and unnecessarily punishing her own 'innocent' children? In a country which had adopted a one-party rule, rigging out some of its popular leaders amounted to political irresponsibility (interview with Karubiu wa Munyi, 24 November 2020). It is no wonder that most of the popular leaders who were rigged out during the 1988 mlolongo [queuing] elections teamed up together to demand the repeal of Section 2A in the old Kenyan constitution that made Kenya a de jure one-party state. Eventually, the contentious section was repealed after the 'opposition' and the civil societies mounted more pressure to the ruling party to open up democratic space, a move that culminated to the repeal of the dictatorial clause. This happened after some protracted street demonstrations, tear-gassing by the trigger-happy police and after scores were tortured and detained in various corners of Kenya.

Was Kenya reverting to the colonial days (1895-1963) when government harassed its own citizens? The likes of 
Karubiu wa Munyi bore the brunt, but were still resolute that only a democratic Kenya was the solution to the myriad of problems facing the post-colonial Kenya. Having fought in the first liberation (1952-1960), the likes of Karubiu wa Munyi found themselves fighting neocolonialism (1980s and early 1990s). They also became heroes of the second liberation, just as they were heroes and heroines in the first liberation (1952-1963). It is no wonder that the ruling party, KANU, lost to the opposition, the National Rainbow Coalition party, in December 2002; and Hon Mwai Kibaki was sworn in as the third president of Kenya on 30 December 2002.

A second regret that Karubiu wa Munyi had, as he was interviewed by the researcher, was that his photo or that of Josphat Kathogo wa Kamoni did not appear anywhere at Mutira Girls' High School; yet it is the duo who built the first two classes. According to wa Munyi (interview 24 November 2010), he gave out money to purchase building materials whilst wa Kamoni, a Native Industrial Training Deport (NITD) Kabete trained contractor/mason in late 1930s, built with his team without requesting any payment. In other words, wa Kamoni paid his own team of workers, from his little pocket, as they used the construction materials that wa Munyi had purchased. In this, wa Munyi regretted that attempts to kill their history (with Josphat Kathogo wa Kamoni) in regard to the construction of Mutira Girls' will remain counterproductive, as recorded history remains across the generations. Even when wa Munyi became the first Treasurer of Mutira Girls' Secondary School Project in 1972, he was unceremoniously removed. In regretting this 'discriminative approach', wa Munyi (interview 24 November 2010) contended that he feared that there could be a conspiracy to deny ex-Mau-Mau detainees like him and wa Kamoni amongst others, their rightful place in history.

A third regret for wa Munyi is the lack of industrious youths and responsible leadership in all sectors of society. Born at the height of colonial and settler land expropriation, in 1925, wa Munyi survived, perhaps, the darkest part of Kenya's historicity through hard work and by demonstrating responsible leadership, a virtue that is now threatened in the 21st century. At the tender age of 16, in 1941, he was already demonstrating responsible leadership through horticultural farming at Rwamburi near Kagumo Town. This was meant not only to make the society food secure but also to earn some income for his family.

It is no wonder that during the so-called Government famine ( $\mathrm{Ng}^{\prime}$ aragu ya Kathirikari) of 1984, when drought caught people unaware, and disorganised the populace in an unprecedented manner, wa Munyi was a philanthropic civic leader who was providing for various families who were hit by this life-threatening episode. Earlier in his lifetimes, he had survived colonial bombs during MauMau war of independence of the 1950s. He was able to survive colonial detention camps, where he was shuttled from Lang'ata, Athi River, Manyani, Kangaita, Kanja-Embu prisons as a measure of dehumanising him; and indeed to psychologically make the African feel that he or she did not matter (1954-1958). Being responsible means that the detention camps could not break his spirit nor could he harbor bitterness. Or was he playing Pauline the theology

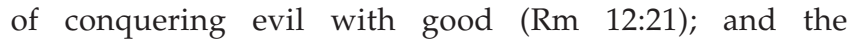
Christological teaching on blessing those who curses a person (Lk 6:28)?

Despite his Ubuntu (responsible and caring) leadership display, wa Munyi who was strong and active by May 2020, whilst at 95 , can be critiqued on the basis that his philosophical foundation did not come out clearly. Put it differently, what is the theoretical frame of mind that informed his social discourses? What type of leadership was he offering: Contingency leadership that contends that there is no single way of leading, total quality management (TQM), which focuses on improving quality and ensure customer satisfaction, situational leadership, where the context and situation determines the nature of leadership needed and the person to offer leadership, instructional leadership, where leaders actively supports day-to-day instructional activities and programmes by modelling desired behaviours and patterns to be observed, transactional leadership that works hard to maintain the status quo, transformative leadership that seeks to empower everyone to take action, or was it the servant leadership, which is a leadership philosophy where the main goal of the leader is to serve? (Gathogo 2016:7-14). Were his selfless duties to God and humanity based on the Christian philosophy of love or was it Africa's Ubuntu philosophy, which is rooted in our cultural heritage? Or did he find himself there, as a public servant without any philosophical base? In my view, though his performance in public duties was above board, his theo-philosophical base was not explicitly known; and this remains the most ambiguous part of his leadership.

\section{Conclusion}

The article set out to explore the lessons that can be drawn in the 21st century from the integrity display and the selfless role of the likes of Councilor Karubiu Munyi amidst regrettable cases or scandals such as those of the NYS of 2018, where over Kenya Shillings 8 bn were reportedly lost in a notorious supplies payment hijack scheme, dubbed as 'supplying air', a phenomenon where faked documents were used to pay ghost suppliers. With over 15 mega corruption scandals remaining unaccounted for, by May 2020, wa Munyi's display of integrity and selfless leadership will have to inform the 21st-century Kenya. In overcoming major life-threatening situations such as Mau-Mau war of liberation (1952-1960), the 1941-1944 drought and massive poverty akin to Spanish Influenza of 1918 and the Corona Virus Disease 2019 (Covid-19), Karubiu Munyi's lifetime inspires the postcolonial Africa in building the view that 'Africa can 
overcome' her own deadly challenges and emerge as the beaming light of the world. Indeed, as the Psalmist (68:31) pontificates, 'Princes shall come out of Egypt; Cush shall soon stretch out her hands to God'.

As a selfless community leader, wa Munyi teamed up with others in order to see to it that Mutira Girls' opened its doors for its Form One class, for the first time, in 1971. Njega Mixed Secondary School opened its doors in 1968, though it picked well in early 1970s. After Hon. J. M. Kariuki laid its foundation in 1969, the 'Njega Secondary School project' appeared set for a major take-off (interview with Rev. Peterson Kiragu, 29 May 2020). Like in the case of Mutira Girls', wa Munyi also played a positive role for Njega Secondary School, now a Boys only secondary school since 1998 (interview with Dr. Geoffrey Njogu, Kinyua Mwai, Dr. John Mararo and Hon Daniel Karaba, 28 May 2020). Through society meetings, lobbying and rallies, he requested the local Mutira coffee farmers' society to provide funds so as to construct permanent dormitories that are visible in the 21st century. He worked hand-inhand with others to realise the dream and eventually delivered the promise. Through the provision of Kirinyaga County Council bursaries, where he was a civic leader for two consecutive terms (1979-1988), he worked hard to ensure that no top-scoring child failed to complete schooling because of lack of school fees. Beyond this, he strived hard to lobby and make feeder roads passable, especially in cases such as Mukonyo-Kiarugu route, amongst others.

\section{As noted in Gathogo (2001):}

$[C]$ orruption is theft from the nation and theft from the nation is always theft from the weakest in the nation: the poor, the old, the disabled, the sick, the children, the new born, and is indeed a contrast to our cherished African hospitality. (p. 39)

In the case of wa Munyi, who avoided embezzling of public funds, he ensured that needy youths and students had bursaries that supported their education, lobbied to the local County Council to build feeder roads, lobbied the MFS to provide funds for the construction of Mutira Girls' dormitories, ensured that Kiamutuira Primary School was built after organising for the allocation of land in Mwea to the original owner, and for becoming the first person to conduct a harambee [fundraising] at Njega Secondary School when he invited the then Chairman of Gikuyu-Embu-Meru Association (Hon Njenga Karume) for fundraising in mid-1970s, amongst other elements of selfless and responsible leadership. In a nutshell, the agenda of selfless, hospitable, integrity-driven and transformative leadership in Kenya is well exhibited in the role of Karubiu wa Munyi, a phenomenon that invites us to rethink where the rain began to beat us. In other words, retracing our steps, and the dreams of the freedom fighters and the pioneer leaders of our modern faith, is an idea that will be needed as we surge on in the 21st century.

\section{Acknowledgements Competing interests}

The author declares that he has no financial or personal relationship which may have inappropriately influenced him in writing this article.

\section{Authors' contribution}

I declare that I am the sole author of this research article.

\section{Ethical consideration}

The author confirms that ethical clearance was not needed for the study.

\section{Funding information}

I appreciate the research output from the research institute of religion and theology, UNISA, that has made this job possible

\section{Data availability statement}

Data sharing is not applicable to this article

\section{Disclaimer}

The views and opinions expressed in this article are those of the author and do not necessarily reflect the official policy or position of any affiliated agency of the author. It is author's own work

\section{References}

Boyes, J., 1912, King of the Wa-Kikuyu: A true story of travel and adventure in Africa, Methuen \& Co. Ltd, London.

Gathogo, J., 2001, The truth about African hospitality: Is there hope for Africa?, The Salt, Mombasa.

Gathogo, J., 2011a, Mutira mission: An African church comes of age (1912-2012), Zapf Chancery, Limuru.

Gathogo, J., 2011b, Pangs of birth in African Christianity: Essays in commemoration of one hundred years of Mutira Anglican mission (1912-2012), Lambert, Saabrucken.

Gathogo, J., 2013a, ‘Unsung heroes and heroines at Mutira Mission, Kenya (1907-2012)', Studia Historiae Ecclesiasticae 39(1), 107-127.

Gathogo, J., 2013b, 'Environmental management and African ancestral resources: Echoes from Mutira Mission, Kenya (1912-2012)', Studia Historiae Ecclesiasticae $39(2), 33-56$

Gathogo, J., 2016, Beyond efficiency in leadership: Exploring effective teacher leadership and the leadership challenges in the twenty-first century, Lambert, Saabrucken.
leadership and

Gathogo, J.M. \& Njogu, C.M., 2019, Chui wa Mararo: The Mau-Mau general who was burnt into ashes, Kairos Book Publishers, Kerugoya.

Korir, A., 2018, 'Standard was there to report state of emergency', Standard, 08 December 2018, viewed 18 August 2019, from https://www.standardmedia. co.ke/article/2001305445/standard-was-there-to-report-state-of-emergency.

Onyango, J., 2019, '15 mega corruption scandals in Kenya which have never been resolved', Tuko, viewed 18 August 2019, from https://www.tuko.co.ke/27453915-mega-corruption-scandals-kenya-resolved.html.

Tablino, P., 2006, Christianity among the nomads: The Catholic communities in Marsabit, Moyale, and Samburu districts of Northern Kenya, vol. 2, Paulines, Nairobi.

Wamagatta, E.N., 1988, 'A bibliography of senior chief Waruhiu wa Kung'u of Githunguri, Kiambu district, 1890-1952', Unpublished MA dissertation, Nairobi Unpublished.

Wamagatta, E.N., 2016, Controversial chiefs in Colonial Kenya: The untold story of senior chief Waruhiu wa Kung'u, 1890-1952, Leington books, New York, NY.

Wanjui, J.B., 2009, My native roots: A family story, University of Nairobi Press, Nairobi.

Wasuna, B., 2019, 'Big corruption scandal amounts that shocked Kenyans in 2018', Daily Nation, 31 December 2018, viewed 18 August 2019, from https://www. nation.co.ke/news/Big-corruption-scandal-amounts-that-shook-Kenyans-in2018/1056-4915472-m10u9bz/index.html. 